\title{
Gene therapy targeting the blood-brain barrier improves neurological symptoms in a model of genetic MCT8 deficiency
}

Sivaraj M. Sundaram, ${ }^{1}$ Adriana Arrulo Pereira, ${ }^{1}$ Hannes Köpke, ${ }^{1}$ Helge Müller-Fielitz, ${ }^{1}$ Meri De Angelis, ${ }^{2}$ Timo D. Müller, ${ }^{2}$ Heike Heuer, ${ }^{3}$ Jakob Körbelin, ${ }^{1,4}$ Markus Krohn, ${ }^{1}$ Jens Mittag, ${ }^{5}$ Ruben Nogueiras, ${ }^{6}$ Vincent Prevot, ${ }^{7}$ Markus Schwaninger ${ }^{1,8}$

${ }^{1}$ Institute for Experimental and Clinical Pharmacology and Toxicology, Center of Brain, Behavior and Metabolism, University of Lübeck, Lübeck, Germany.

${ }^{2}$ Institute for Diabetes and Obesity, Helmholtz Zentrum Munich, Munich, and German Center for Diabetes Research (DZD), Germany.

${ }^{3}$ Department of Endocrinology, Diabetes and Metabolism, University Hospital Essen, University Duisburg-Essen, Essen, Germany.

${ }^{4}$ Department of Oncology, Hematology and Bone Marrow Transplantation, UKE Hamburg-Eppendorf, Hamburg, Germany.

${ }^{5}$ Institute for Endocrinology and Diabetes, Center of Brain, Behavior and Metabolism, University of Lübeck, Lübeck, Germany.

${ }^{6}$ Department of Physiology, CIMUS, University of Santiago de Compostela-Instituto de Investigación Sanitaria, Santiago de Compostela, Spain.

${ }^{7}$ Univ. Lille, Inserm, CHU Lille, Laboratory of Development and Plasticity of the Neuroendocrine Brain, Lille Neuroscience \& Cognition, UMR-S 1172, European Genomic Institute for Diabetes (EGID), Lille, France.

${ }^{8}$ DZHK (German Research Centre for Cardiovascular Research), Hamburg-Lübeck-Kiel, Germany.

Address correspondence to: Markus Schwaninger, Institute for Experimental and Clinical Pharmacology and Toxicology, University of Lübeck, Ratzeburger Allee 160, 23562 Lübeck, Germany, Phone: +49-451-31017200, E-Mail: markus.schwaninger@uni-luebeck.de

Conflict-of-interest statement: The authors have declared that no conflict of interest exists. 
bioRxiv preprint doi: https://doi org/10.1101/2021.12.05.471343; this version posted December 9,2021 . The copyright holder for this preprint (which was not certified by peer review) is the author/funder, who has granted bioRxiv a license to display the preprint in perpetuity. It is made available under aCC-BY 4.0 International license.

\section{Abstract}

The solute carrier monocarboxylate transporter 8 (MCT8) transports the thyroid hormones thyroxine and tri-iodothyronine (T3) across cell membranes. MCT8 gene deficiency, termed Allan-HerndonDudley syndrome, is an important cause of X-linked intellectual and motor disability. As no treatment of the neurological symptoms is available yet, we tested a gene replacement therapy in Mct8- and Oatp1c1-deficient mice as a well-established model of the disease. Here, we report that targeting brain endothelial cells for Mct8 expression by intravenously injecting the vector AAV-BR1-Mct8 increased T3 levels in the brain and ameliorated morphological and functional parameters associated with the disease. Importantly, the therapy resulted in a long-lasting improvement in motor coordination. Thus, the data support the concept that MCT8 mediates the transport of thyroid hormones into the brain and indicate that a readily accessible vascular target can help overcome the consequences of the severe disability associated with MCT8 deficiency. 
bioRxiv preprint doi: https://doi org/10.1101/2021.12.05.471343; this version posted December 9,2021 . The copyright holder for this preprint (which was not certified by peer review) is the author/funder, who has granted bioRxiv a license to display the preprint in perpetuity. It is made available under aCC-BY 4.0 International license.

\section{Introduction}

The thyroid hormones (THs) thyroxine (T4) and tri-iodothyronine (T3) are critical for the function of the central nervous system (CNS). Severe hypothyroidism causes cognitive deficits and other neurological symptoms (Wood-Allum \& Shaw, 2014). Mild TH deficiency has been associated with major depression and dementia (Dwyer et al, 2020; Tan \& Vasan, 2009). In the CNS, nuclear receptors and deiodinases maintain $\mathrm{TH}$ homeostasis but the initial step required for the action of THs is their cellular uptake by solute carriers. Here, monocarboxylate transporter 8 (MCT8) and organic anion transporter polypeptide 1c1 (OATP1C1) transport THs in vivo (Bernal et al, 2015; Groeneweg et al, 2020). Mutations of the X-linked MCT8 gene (SLC16A2) cause severe intellectual disability, motor dysfunction, and peripheral thyrotoxicosis (Allan-Herndon-Dudley syndrome, AHDS)(Dumitrescu et al, 2004; Friesema et al, 2004). It has been estimated that MCT8 mutations are responsible for almost $4 \%$ of all X-linked intellectual disabilities (Visser et al, 2013). Affected boys appear normal at birth but show developmental delay and feeding problems in the first year of life. Some patients cannot fully control their head, speak, or walk. Other motor symptoms include muscle weakness, gait ataxia, and dystonia. TH analogues improved the peripheral thyroid status (Groeneweg et al, 2019; Verge et al, 2012), but treatment of the CNS symptoms that are key to patients' disabilities is still not available and represents an unmet medical need.

Neuropathological changes underlying symptoms of MCT8 deficiency include an altered cerebellar structure, lack of parvalbumin-positive interneurons, delayed myelination, and oligodendrocyte dysfunction (Lopez-Espindola et al, 2014), indicative of a global TH deficiency in the CNS. Interestingly, brain barriers, including endothelial cells, express MCT8 into adulthood (LopezEspindola et al, 2019; Wilpert et al, 2020) pointing to a pivotal role of MCT8 in TH transport through the brain barriers.

Mouse studies support this hypothesis. Unlike human patients, Mct8 ${ }^{-/}$mice do not show a neurological phenotype (Mayerl et al, 2014; Trajkovic et al, 2007); in mice but not in humans, OATP1C1 functions as a second transporter in brain endothelial cells and epithelial cells of the 
bioRxiv preprint doi: https://doi org/10.1101/2021.12 05.471343; this version posted December 9,2021 . The copyright holder for this preprint (which was not certified by peer review) is the author/funder, who has granted bioRxiv a license to display the preprint in perpetuity. It is made available under aCC-BY 4.0 International license.

choroid plexus (Roberts et al, 2008), suggesting that OATP1C1 compensates for MCT8 deficiency. Indeed, double knockout (DKO) of Mct8 and Oatp1c1 (S/co1c1) resembles the neuropathological changes of human MCT8 mutations thus providing a suitable mouse model of the disease (Mayerl et al., 2014). The observation that the barrier-specific OATP1C1 can compensate for MCT8 deletion supports the assumption that МСТ8 is critical for TH transport across the brain barriers (Vatine et al, 2017) but definitive in vivo evidence is lacking.

The assumption that impaired TH transport through the blood-brain barrier is the primary mechanism underlying symptoms of MCT8 deficiency suggests a novel gene therapy approach, as endothelial cells of the blood-brain barrier, unlike neural cells, are directly accessible to intravenously administered gene vectors (Körbelin et al, 2016). In the present study, we tested this concept in Mct8/Oatp1c1 DKO mice. Our data show that AAV-mediated expression of Mct8 in brain endothelial cells can prevent neurological pathology, identifying a critical role of MCT8 function in brain barriers and pointing to a new treatment strategy for AHDS patients normalizing TH levels in the CNS. 
bioRxiv preprint doi: https://doi org/10.1101/2021.12.05.471343; this version posted December 9,2021 . The copyright holder for this preprint (which was not certified by peer review) is the author/funder, who has granted bioRxiv a license to display the preprint in perpetuity. It is made available under aCC-BY 4.0 International license.

\section{Results}

For targeted expression of Mct8 in the blood-brain barrier, we generated a viral Mct8 gene vector

(Fig 1A), packaged in the AAV-BR1 capsid (AAV-BR1-Mct8), which selectively transduces brain endothelial cells in vivo (Körbelin et al., 2016). After incubating primary brain endothelial cells (PBECs) from Mct8/Oatp1c1 DKO mice with AAV-BR1-Mct8, about $10 \%$ of the cells immunostained for MCT8, indicating transduction (Fig 1B). To determine whether virally transduced MCT8 was functional, we measured PBEC uptake of T3. Untreated PBECs from DKO mice did not take up T3 (Fig 1C). However, transduction of PBECs with AAV-BR1-Mct8 enabled T3 uptake, and silychristin, an MCT8 inhibitor, blocked it, confirming that MCT8 is active after viral transduction (Fig 1C)(Johannes et al, 2016).

For in vivo testing, we injected AAV-BR1-Mct8 intravenously in mice at postnatal day 0 (P0) and investigated the animals at various time points (Fig 1D). At P33, immunohistochemistry demonstrated robust MCT8 expression in brain endothelial cells and in some neurons and astrocytes, too, as previously described for the AAV-BR1 capsid (Körbelin et al., 2016) (Fig 1E). To quantify the transduction rate of brain endothelial cells by AAV-BR1-Mct8, we injected the vector in P0 mice and prepared PBECs from these animals at P33. Of PBECs derived from AAV-BR1-Mct8-treated mice, 8.6 $\pm 1.1 \%$ expressed MCT8 (Fig 1F). However, the true transduction rate might be higher as immunofluorescence staining sensitivity for MCT8 was limited and did not detect the downregulated endogenous MCT8 levels of cultured control cells (Fig 1F)(Sabbagh \& Nathans, 2020).

In the CNS, endothelial cells are non-proliferative and quiescent after mice reach an age of $14-30$ days (Harb et al, 2013). Thus, loss of the non-integrating AAV vector after P33 is not expected. Accordingly, in situ hybridization and immunofluorescence staining showed that Mct8 was still expressed in cerebral vessels of P120 DKO mice that received AAV-BR1-Mct8 at P0 but not in other tissues, such as pituitary, kidney, and liver (Fig 1G, Supplemental Fig 1A, B, C), confirming the known brain tropism of AAV-BR1 after intravenous injection (Körbelin et al., 2016). Importantly, targeting 
bioRxiv preprint doi: https://doi org/10.1101/2021.12 05.471343. this version posted December 9,2021 . The copyright holder for this preprint (which was not certified by peer review) is the author/funder, who has granted bioRxiv a license to display the preprint in perpetuity. It is made available under aCC-BY 4.0 International license.

brain endothelial cells with AAV-BR1-Mct8 did not impair the blood-brain barrier, nor did it induce signs of endothelial cell death (Supplemental Fig 2).

As brain endothelial cell transduction sustained Mct8 expression, we wondered whether it would affect TH levels in the brain. As shown previously, Mct8 deletion (on an Oatp1c1 ${ }^{-1}$ background) lowered T4 and T3 concentrations in the brain (Fig 1H) (Mayerl et al., 2014). Importantly, AAV-BR1Mct8 administration to PO mice increased cerebral concentrations of the active hormone T3 while it had no detectable effect on brain levels of the pro-hormone T4 at P21 (Fig 1H). The lack of effect on T4 levels may be due to an enhanced metabolism of T4 to T3 in DKO mice (Groeneweg et al., 2020). Notably, the increase in cerebral T3 levels as seen in treated DKO mice only slightly affected the hypothalamus-pituitary-thyroid (HPT) axis. In situ hybridization showed that Trh in the paraventricular nucleus and Tshb in the pituitary gland remained at the elevated levels characteristic for DKO mice (Supplemental Fig 3A)(Mayerl et al., 2014). Moreover, treatment with AAV-BR1-Mct8 had little effect on the elevated T3 and reduced T4 serum concentrations in DKO mice (Supplemental Fig 3B) and none on the high expression of the TH-regulated genes Gpd2 and Dio1 in the liver or the reduced body weight characteristic of DKO mice (Supplemental Fig 4A and 4B). The fact that AAVBR1-Mct8 restores Mct8 expression in the endothelial blood-brain barrier but spares tanycytes, the specialized glial cells that contain high amounts of MCT8 in the normal hypothalamus, might explain the lack of a marked effect on the HPT axis (Wilpert et al., 2020). Although AAV-BR1-Mct8 would not completely normalize serum TH concentrations, in AHDS patients peripheral hyperthyroidism can be managed by the antithyroid drug propylthiouracil plus T4 or by TH analogues (Groeneweg et al., 2019; Verge et al., 2012; Wémeau et al, 2008).

Supply of T3 to the brain could potentially improve neurological symptoms of MCT8 deficiency. The absence of MCT8 and OATP1C1 slows down Purkinje cell dendritogenesis (Mayerl et al., 2014). Consequently, the molecular layer of the cerebellum consisting of dendrites of calbindin-positive Purkinje cells was thinner in untreated P12 DKO mice than in controls (Fig 2A). After injecting AAVBR1-Mct8, however, the molecular layer was thicker than in untreated DKO mice (Fig 2A) and there 
bioRxiv preprint doi: https://doi org/10.1101/2021.12.05.471343; this version posted December 9,2021 . The copyright holder for this preprint (which was not certified by peer review) is the author/funder, who has granted bioRxiv a license to display the preprint in perpetuity. It is made available under aCC-BY 4.0 International license.

were more interneurons expressing the marker genes GAD67 and parvalbumin in the somatosensory cortex (Fig 2A).

AAV-BR1-Mct8 treatment at P0 had a persistent effect. At P33, AAV-BR1-Mct8-treated DKO mice showed significantly thicker layers II-VI containing NeuN-positive neurons in the somatosensory cortex than untreated DKO animals (Fig 2B). Consistent with the findings at P12, AAV-BR1-Mct8 treatment improved GAD67 fluorescence intensity and the number of parvalbumin-positive cells in the somatosensory cortex of DKO mice at P33 (Fig 2B).

To determine whether sustained Mct8 expression improves neuronal function in the long term, we analyzed the expression of established TH-regulated genes by using in situ hybridization at P120. Neurogranin (Nrgn, Rc3) is known to be upregulated by THs in medium spiny neurons of the striatum (Iniguez et al, 1992). Nrgn expression was reduced in the striatum of untreated DKO mice (Fig 2C)(Mayerl et al., 2014), but after administration of AAV-BR1-Mct8, expression was markedly higher than in untreated DKO animals (Fig 2C). Likewise, the TH-regulated gene Kruppel-like factor 9 (Klf9) encoding a neuronal transcription factor was slightly, but nonsignificantly induced by AAV-BR1-Mct8 treatment of DKO mice (Fig 2C). Moreover, AAV-BR1-Mct8 injection normalized the cortical expression of the TH-regulated Hairless (Hr) in DKO mice at P120 (Potter et al, 2002)(Fig 2C). These findings demonstrate that AAV-BR1-Mct8 treatment at PO has a long-lasting effect on neuronal morphology and gene expression.

Magnetic resonance imaging and autopsy studies showed that myelination is abnormal or delayed in patients with MCT8 deficiency (Iwayama et al, 2021; Lopez-Espindola et al., 2014), reflecting the critical role of THs in postnatal myelination (Bernal et al., 2015). At the cellular level, THs promote differentiation of oligodendrocytes that produce myelin (Barres et al, 1994). As expected from the lack of THs in the CNS, DKO mice had significantly fewer Olig2-positive oligodendrocytes in the corpus callosum than controls at P33 (Fig 3A). AAV-BR1-Mct8 treatment at P0 slightly, but nonsignificantly attenuated the decrease in Olig2-positive cells (Fig 3A). Under the influence of TH, oligodendrocytes produce myelin basic protein (MBP), a key component of CNS myelin (Farsetti et al, 
bioRxiv preprint doi: https:/doi org/10.1101/2021.12 05.471343; this version posted December 9,2021 . The copyright holder for this preprint (which was not certified by peer review) is the author/funder, who has granted bioRxiv a license to display the preprint in perpetuity. It is made available under aCC-BY 4.0 International license.

1991). Like human patients, DKO mice present with low MBP expression in the cortex and corpus callosum (Fig 3B)(Lopez-Espindola et al., 2014; Mayerl et al., 2014). However, AAV-BR1-Mct8 treatment at PO increased MBP levels in the cortex of DKO mice (Fig 3B). MBP mediates myelin compaction (Readhead et al, 1987). Accordingly, AAV-BR1-Mct8 treatment increased levels of compact myelin in the corpus callosum as shown by FluoroMyelin staining, indicating better gross myelination (Fig 3C).

MCT8-deficient patients suffer from coordination deficits. Like AHDS patients, DKO mice exhibited locomotor deficiencies, including impaired motor coordination and learning in comparison to littermate controls when investigated in the rotarod test at P120 (Fig 4A)(Mayerl et al., 2014). However, a single intravenous injection of AAV-BR1-Mct8 at P0 significantly improved DKO mice performance and motor learning (Fig 4A). In the beam walk, another test of coordination and balance, DKO mice treated with AAV-BR1-Mct8 crossed the beam faster than untreated DKO and tended to make fewer errors (Fig 4B, C). Moreover, grip strength tended to be greater in AAV-BR1Mct8-treated DKO mice (Fig 4D). 
bioRxiv preprint doi: https://doi org/10.1101/2021.12.05.471343; this version posted December 9,2021 . The copyright holder for this preprint (which was not certified by peer review) is the author/funder, who has granted bioRxiv a license to display the preprint in perpetuity. It is made available under aCC-BY 4.0 International license.

\section{Discussion}

Our study reports a novel gene therapy for MCT8 deficiency, a major cause of X-linked intellectual disability. A previous study expressed MCT8 in mice with the help of the AAV9 capsid that penetrates the blood-brain barrier and transduces neural cells but expression in parenchymal cells did not correct low TH concentrations in the brain after intracerebroventricular injection of the vector, presumably because the blood-brain barrier transport of THs was still compromised (Iwayama et al, 2016). Moreover, the unspecific tropism of AAV9 and its high liver transduction are associated with side effects (Chand et al, 2021; Walia et al, 2015). In contrast, targeting the small endothelial cell population in the present study was sufficient to supply T3 to the brain and to ameliorate symptoms of MCT8 deficiency in a mouse model, although the transduction rate of endothelial cells was rather low. Thus, endothelial cells are a critical site for MCT8 function after birth.

Normal brain development requires TH action already before birth, but how THs cross the prenatal blood-brain barrier is still unclear. Human brain vessels express MCT8 already at gestational week 14 (Lopez-Espindola et al., 2019). Lower brain TH concentrations in an MCT8-deficient fetus suggest that MCT8 plays a role in fetal TH transport (Lopez-Espindola et al., 2014). On the other hand, patients with MCT8 deficiency are normal at birth and only develop symptoms during the first year of life (Dumitrescu et al., 2004; Friesema et al., 2004; Groeneweg et al., 2020). Our study now provides functional data that postnatal reconstitution of MCT8 is sufficient to prevent the neurological phenotype of the disease, at least partially.

MCT8 expression could be directed to the neonatal blood-brain barrier by using an AAV vector with high selectivity for brain endothelial cells (Körbelin et al., 2016). This approach improved transcriptional and morphological parameters of the disease already after 12 days. Importantly, the effect persisted at the behavioral and transcriptional level into adulthood. Thus, brain endothelial cell-specific gene therapy emerges as a novel treatment of the disabling neurological signs of AHDS. The intravenous route and postnatal administration may facilitate translation to clinical application. 


\section{Materials and methods}

\section{Mice}

Breeding pairs were set up among $\mathrm{Mct8}^{-/+} ;$Oatp1c1 ${ }^{-/+}$and $\mathrm{Mct8}^{-/ \mathrm{v}} ;$ Oatp1c1 ${ }^{-/+}$mice to obtain $\mathrm{Mct}^{-1-}$

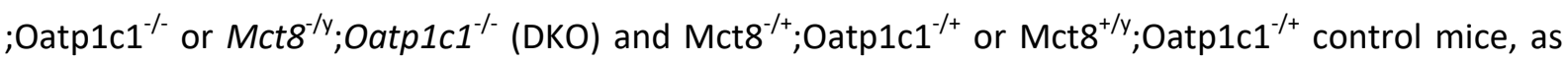
reported previously (Mayerl et al., 2014). Detailed information is provided in Supplemental Methods. Mice were randomized into treatment groups. Experimenters were blinded to group allocation in the phenotype analysis.

\section{Statistical analysis}

$P$ values $\leq 0.05$ were considered statistically significant. We did not exclude outliers, unless indicated. ANOVA and t-test were only applied if assumptions were met, i.e., datasets were examined for Gaussian distribution using the D'Agostino-Pearson or Kolmogrov-Smirnov test, aided by visual inspection of the data, and homogeneity of variances by Brown-Forsythe test. Mostly, Holm-Sidak posthoc analysis was applied to test the significance between groups.

\section{Study approval}

All animal experiments were performed according to German animal welfare regulations, and experimental protocols were approved by the local animal ethics committee (No. 11-1-17, MELUND, Kiel, Germany). 
bioRxiv preprint doi: https://doi org/10.1101/2021.12.05.471343; this version posted December 9,2021 . The copyright holder for this preprint (which was not certified by peer review) is the author/funder, who has granted bioRxiv a license to display the preprint in perpetuity. It is made available under aCC-BY 4.0 International license.

\section{Author contributions}

J.M. and M.S. designed the study. S.M.S., A.A.P., H.K., H.M.F., M.D.A., J.K., M.K., and C.L.S. performed experiments and analyzed the data. H.H., T.D.M., R.N., V.P., and J.M. provided tools, samples, and conceptual support. S.M.S, A.A.P., R.N., V.P., and M.S. drafted the manuscript. All authors revised the manuscript for important intellectual content.

\section{Acknowledgement}

We thank Ines Stölting, Wiebke Brandt, Beate Lembrich, Frauke Spiecker (Pharmacology), and Christian L. Schmidt (Isotope laboratory) for their kind support. This work was supported by the European Research Council (ERC) Synergy Grant-2019-WATCH-810331 to V. P., R. N., and M. S., by grants of the Deutsche Forschungsgemeinschaft (MU-3743/1-1 to H.M.F., CRC/TR296 to H.M.F., T.M., H.H., J.M. and M. S.) and by the Sherman family funds to H.H.. 
bioRxiv preprint doi: https://doi.org/10.1101/2021.12.05.471343; this version posted December $9,2021$. The copyright holder for this preprint (which was not certified by peer review) is the author/funder, who has granted bioRxiv a license to display the preprint in perpetuity. It is made available under aCC-BY 4.0 International license.

\section{References}

Barres BA, Lazar MA, Raff MC (1994) A novel role for thyroid hormone, glucocorticoids and retinoic acid in timing oligodendrocyte development. Development 120: 1097-1108

Bernal J, Guadano-Ferraz A, Morte B (2015) Thyroid hormone transporters--functions and clinical implications. Nat Rev Endocrinol 11: 406-417

Chand D, Mohr F, McMillan H, Tukov FF, Montgomery K, Kleyn A, Sun R, Tauscher-Wisniewski S, Kaufmann P, Kullak-Ublick $G$ (2021) Hepatotoxicity following administration of onasemnogene abeparvovec (AVXS-101) for the treatment of spinal muscular atrophy. Journal of Hepatology 74: 560-566

Dumitrescu AM, Liao XH, Best TB, Brockmann K, Refetoff S (2004) A novel syndrome combining thyroid and neurological abnormalities is associated with mutations in a monocarboxylate transporter gene. Am J Hum Genet 74: 168-175

Dwyer JB, Aftab A, Radhakrishnan R, Widge A, Rodriguez Cl, Carpenter LL, Nemeroff CB, McDonald WM, Kalin NH, Biomarkers APACoRTFoN et al (2020) Hormonal Treatments for Major Depressive Disorder: State of the Art. Am J Psychiatry 177: 686-705

Farsetti A, Mitsuhashi T, Desvergne B, Robbins J, Nikodem VM (1991) Molecular basis of thyroid hormone regulation of myelin basic protein gene expression in rodent brain. J Biol Chem 266: 2322623232

Friesema EC, Grueters A, Biebermann H, Krude H, von Moers A, Reeser M, Barrett TG, Mancilla EE, Svensson J, Kester MH et al (2004) Association between mutations in a thyroid hormone transporter and severe X-linked psychomotor retardation. Lancet 364: 1435-1437

Groeneweg S, Peeters RP, Moran C, Stoupa A, Auriol F, Tonduti D, Dica A, Paone L, Rozenkova K, Malikova J et al (2019) Effectiveness and safety of the tri-iodothyronine analogue Triac in children and adults with МСT8 deficiency: an international, single-arm, open-label, phase 2 trial. Lancet Diabetes Endocrinol 7: 695-706

Groeneweg S, van Geest FS, Peeters RP, Heuer H, Visser WE (2020) Thyroid Hormone Transporters. Endocr Rev 41: bnz008

Harb R, Whiteus C, Freitas C, Grutzendler J (2013) In vivo imaging of cerebral microvascular plasticity from birth to death. J Cereb Blood Flow Metab 33: 146-156

Iniguez MA, Rodriguez-Pena A, Ibarrola N, Morreale de Escobar G, Bernal J (1992) Adult rat brain is sensitive to thyroid hormone. Regulation of RC3/neurogranin mRNA. J Clin Invest 90: 554-558 Iwayama H, Liao XH, Braun L, Barez-Lopez S, Kaspar B, Weiss RE, Dumitrescu AM, Guadano-Ferraz A, Refetoff S (2016) Adeno Associated Virus 9-Based Gene Therapy Delivers a Functional

Monocarboxylate Transporter 8, Improving Thyroid Hormone Availability to the Brain of Mct8Deficient Mice. Thyroid 26: 1311-1319

Iwayama H, Tanaka T, Aoyama K, Moroto M, Adachi S, Fujisawa Y, Matsuura H, Takano K, Mizuno H, Okumura A (2021) Regional Difference in Myelination in Monocarboxylate Transporter 8 Deficiency: Case Reports and Literature Review of Cases in Japan. Front Neurol 12: 657820

Johannes J, Jayarama-Naidu R, Meyer F, Wirth EK, Schweizer U, Schomburg L, Kohrle J, Renko K (2016) Silychristin, a Flavonolignan Derived From the Milk Thistle, Is a Potent Inhibitor of the Thyroid Hormone Transporter MCT8. Endocrinology 157: 1694-1701

Körbelin J, Dogbevia G, Michelfelder S, Ridder DA, Hunger A, Wenzel J, Seismann H, Lampe M, Bannach J, Pasparakis M et al (2016) A brain microvasculature endothelial cell-specific viral vector with the potential to treat neurovascular and neurological diseases. EMBO Molecular Medicine 8: 609-625

Lopez-Espindola D, Garcia-Aldea A, Gomez de la Riva I, Rodriguez-Garcia AM, Salvatore D, Visser TJ, Bernal J, Guadano-Ferraz A (2019) Thyroid hormone availability in the human fetal brain: novel entry pathways and role of radial glia. Brain Struct Funct 224: 2103-2119

Lopez-Espindola D, Morales-Bastos C, Grijota-Martinez C, Liao XH, Lev D, Sugo E, Verge CF, Refetoff S, Bernal J, Guadano-Ferraz A (2014) Mutations of the thyroid hormone transporter MCT8 cause prenatal brain damage and persistent hypomyelination. J Clin Endocrinol Metab 99: E2799-2804 
bioRxiv preprint doi: https://doi.org/10.1101/2021.12.05.471343; this version posted December 9, 2021. The copyright holder for this preprint (which was not certified by peer review) is the author/funder, who has granted bioRxiv a license to display the preprint in perpetuity. It is made available under aCC-BY 4.0 International license.

Mayerl S, Müller J, Bauer R, Richert S, Kassmann CM, Darras VM, Buder K, Boelen A, Visser TJ, Heuer H (2014) Transporters MCT8 and OATP1C1 maintain murine brain thyroid hormone homeostasis. J Clin Invest 124: 1987-1999

Potter GB, Zarach JM, Sisk JM, Thompson CC (2002) The thyroid hormone-regulated corepressor hairless associates with histone deacetylases in neonatal rat brain. Mol Endocrinol 16: 2547-2560 Readhead C, Popko B, Takahashi N, Shine HD, Saavedra RA, Sidman RL, Hood L (1987) Expression of a myelin basic protein gene in transgenic shiverer mice: correction of the dysmyelinating phenotype. Cell 48: 703-712

Roberts LM, Woodford K, Zhou M, Black DS, Haggerty JE, Tate EH, Grindstaff KK, Mengesha W, Raman C, Zerangue N (2008) Expression of the thyroid hormone transporters monocarboxylate transporter-8 (SLC16A2) and organic ion transporter-14 (SLCO1C1) at the blood-brain barrier. Endocrinology 149: 6251-6261

Sabbagh MF, Nathans J (2020) A genome-wide view of the de-differentiation of central nervous system endothelial cells in culture. Elife 9: e51276

Tan ZS, Vasan RS (2009) Thyroid function and Alzheimer's disease. J Alzheimers Dis 16: 503-507 Trajkovic M, Visser TJ, Mittag J, Horn S, Lukas J, Darras VM, Raivich G, Bauer K, Heuer H (2007) Abnormal thyroid hormone metabolism in mice lacking the monocarboxylate transporter 8. J Clin Invest 117: 627-635

Vatine GD, Al-Ahmad A, Barriga BK, Svendsen S, Salim A, Garcia L, Garcia VJ, Ho R, Yucer N, Qian T et al (2017) Modeling Psychomotor Retardation using iPSCs from MCT8-Deficient Patients Indicates a Prominent Role for the Blood-Brain Barrier. Cell Stem Cell 20: 831-843 e835

Verge CF, Konrad D, Cohen M, Di Cosmo C, Dumitrescu AM, Marcinkowski T, Hameed S, Hamilton J, Weiss RE, Refetoff S (2012) Diiodothyropropionic acid (DITPA) in the treatment of MCT8 deficiency. J Clin Endocrinol Metab 97: 4515-4523

Visser WE, Vrijmoeth P, Visser FE, Arts WF, van Toor H, Visser TJ (2013) Identification, functional analysis, prevalence and treatment of monocarboxylate transporter 8 (MCT8) mutations in a cohort of adult patients with mental retardation. Clin Endocrinol (Oxf) 78: 310-315

Walia JS, Altaleb N, Bello A, Kruck C, LaFave MC, Varshney GK, Burgess SM, Chowdhury B, Hurlbut D, Hemming R et al (2015) Long-term correction of Sandhoff disease following intravenous delivery of rAAV9 to mouse neonates. Mol Ther 23: 414-422

Wémeau JL, Pigeyre M, Proust-Lemoine E, D'Herbomez M, Gottrand F, Jansen J, Visser TJ, Ladsous M (2008) Beneficial Effects of Propylthiouracil plusl-Thyroxine Treatment in a Patient with a Mutation inMCT8. The Journal of Clinical Endocrinology \& Metabolism 93: 2084-2088

Wilpert NM, Krueger M, Opitz R, Sebinger D, Paisdzior S, Mages B, Schulz A, Spranger J, Wirth EK, Stachelscheid $\mathrm{H}$ et al (2020) Spatiotemporal Changes of Cerebral Monocarboxylate Transporter 8 Expression. Thyroid 30: 1366-1383

Wood-Allum CA, Shaw PJ (2014) Thyroid disease and the nervous system. Handbook of clinical neurology 120: 703-735 
bioRxiv preprint doi: https://doi.org/10.1101/2021.12.05.471343; this version posted December 9, 2021. The copyright holder for this preprint (which was not certified by peer review) is the author/funder, who has granted bioRxiv a license to display the preprint in perpetuity. It is made available under aCC-BY 4.0 International license.

Figure 1

A

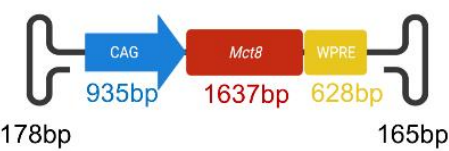

C

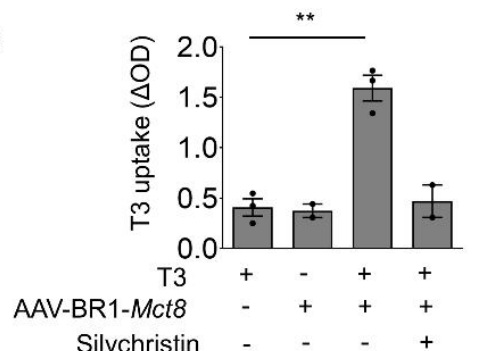

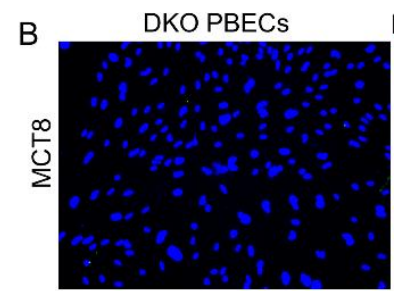

D

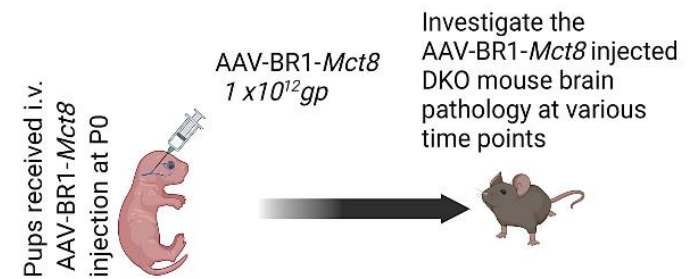

DKO PBECs +AAV-BR1-Mct8

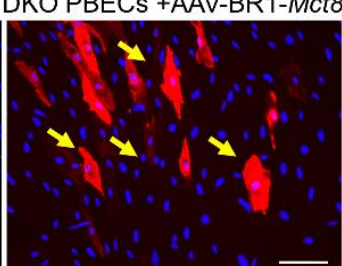
DKO+AAV-BR1

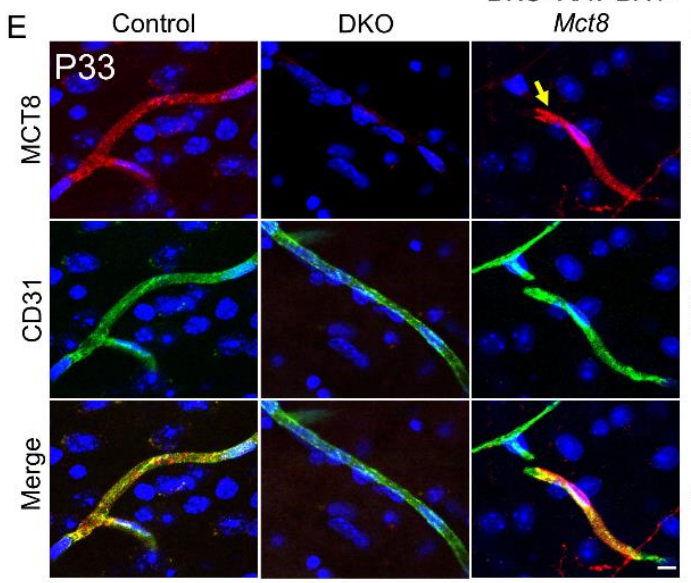

DKO+AAV-BR1-

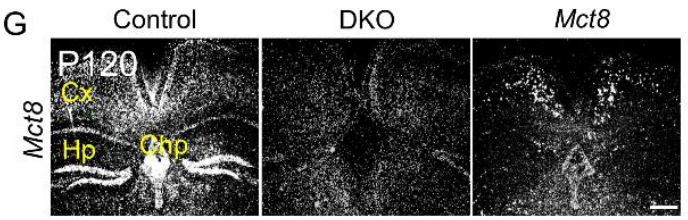

DKO+AAV-BR1-
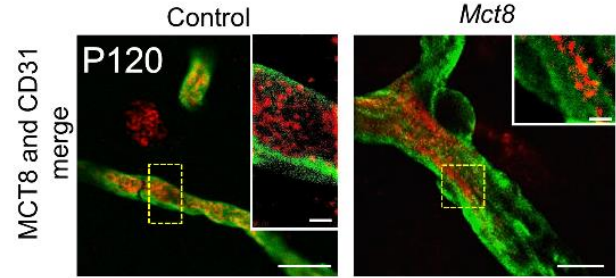

DKO+AAV-BR1-

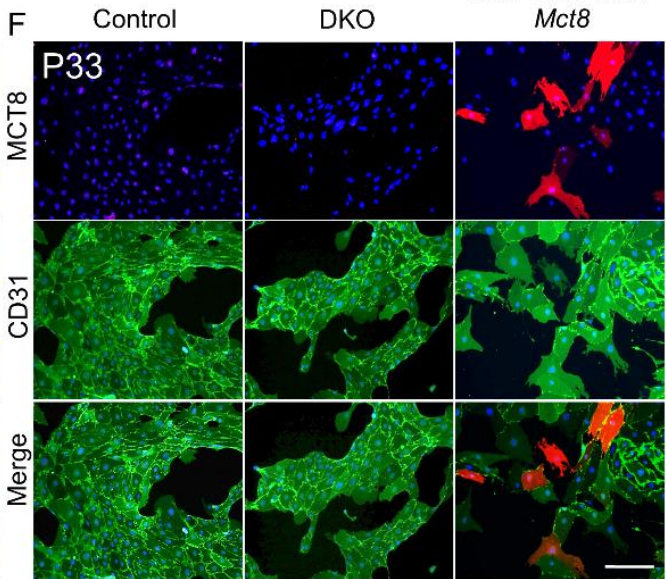

$\mathrm{H}$
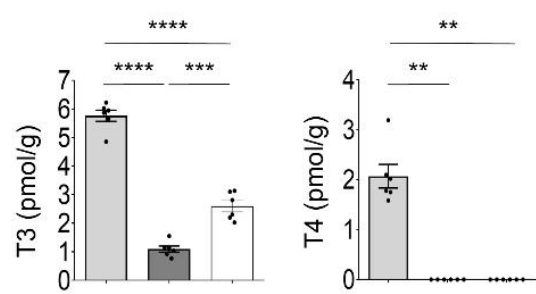

Figure 1. Intravenous administration of AAV-BR1-Mct8 enables the expression of Mct8 in brain endothelial cells and T3 transport into the CNS.

(A) Schematic illustration of AAV-BR1-Mct8 vectors to transduce brain endothelial cells. WPRE, woodchuck hepatitis posttranscriptional regulatory element. (B) After transduction of primary brain endothelial cells (PBECS) of DKO mice in vitro with AAV-BR1-Mct8, MCT8 was expressed. MCT8 was detected by fluorescence immunostaining and nuclei with DAPI. Arrows, MCT8-positive cells. Scale bar, $100 \mu \mathrm{m}$. (C) T3 uptake in DKO PBECs was enhanced by AAV-BR1-Mct8 treatment in vitro. Results were obtained from three independent cell culture preparations. ${ }^{* *} P=0.0015$ (unpaired t test). (D) 
bioRxiv preprint doi: https://doi org/10.1101/2021.12 05.471343. this version posted December 9,2021 . The copyright holder for this preprint (which was not certified by peer review) is the author/funder, who has granted bioRxiv a license to display the preprint in perpetuity. It is made available under aCC-BY 4.0 International license.

Schematic of the experimental design. gp, genomic particles. (E) MCT8 expression (arrow) in CD31positive endothelial cells of control or DKO mice that received AAV-BR1-Mct8 at P0. Fluorescence immunostaining for MCT8 and CD31 was performed at P33. Scale bar, $100 \mu \mathrm{m}$. (F) MCT8 expression (arrow) in PBECs prepared from P33 mice that received AAV-BR1-Mct8 at P0 (MCT8-positive cells, $8.6 \pm 1.1 \%$ of CD31-positive PBECs in four independent cell culture preparations, with one mouse per cell culture preparation). (G) At P120, Mct8 mRNA (upper panel) and MCT8 protein (lower panel, red) were detected in control and DKO mice treated with AAV-BR1-Mct8 at P0. CD31, green. Scale bar, $100 \mu \mathrm{m}$. Cx, cortex; Chp, choroid plexus; Hp, hippocampus. (H) T3 and T4 concentrations in the brain of control and DKO mice that received AAV-BR1-Mct8 at PO and were sacrificed at P21. One-way ANOVA for T3, $F(2 / 10)=159, P<0.0001$. One-way ANOVA for T4, $F(2 / 10)=556.2, P<0.0001$. Each dot represents one animal. Means \pm SEM are shown. ${ }^{* * *}, P=0.0004 ; * * * *, P<0.0001$ (Holm-Sidak's posthoc test). 
bioRxiv preprint doi: https:/doi.org/10.1101/2021.12.05.471343: this version posted December 9, 2021. The copyright holder for this preprint (which was not certified by peer review) is the author/funder, who has granted bioRxiv a license to display the preprint in perpetuity. It is made available under aCC-BY 4.0 International license.

Figure 2
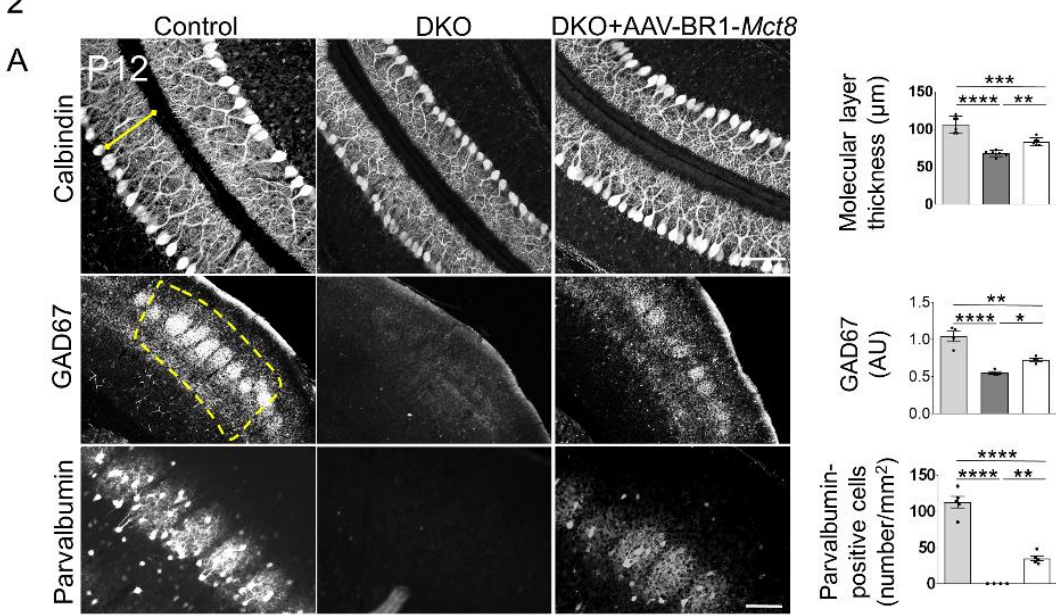

B
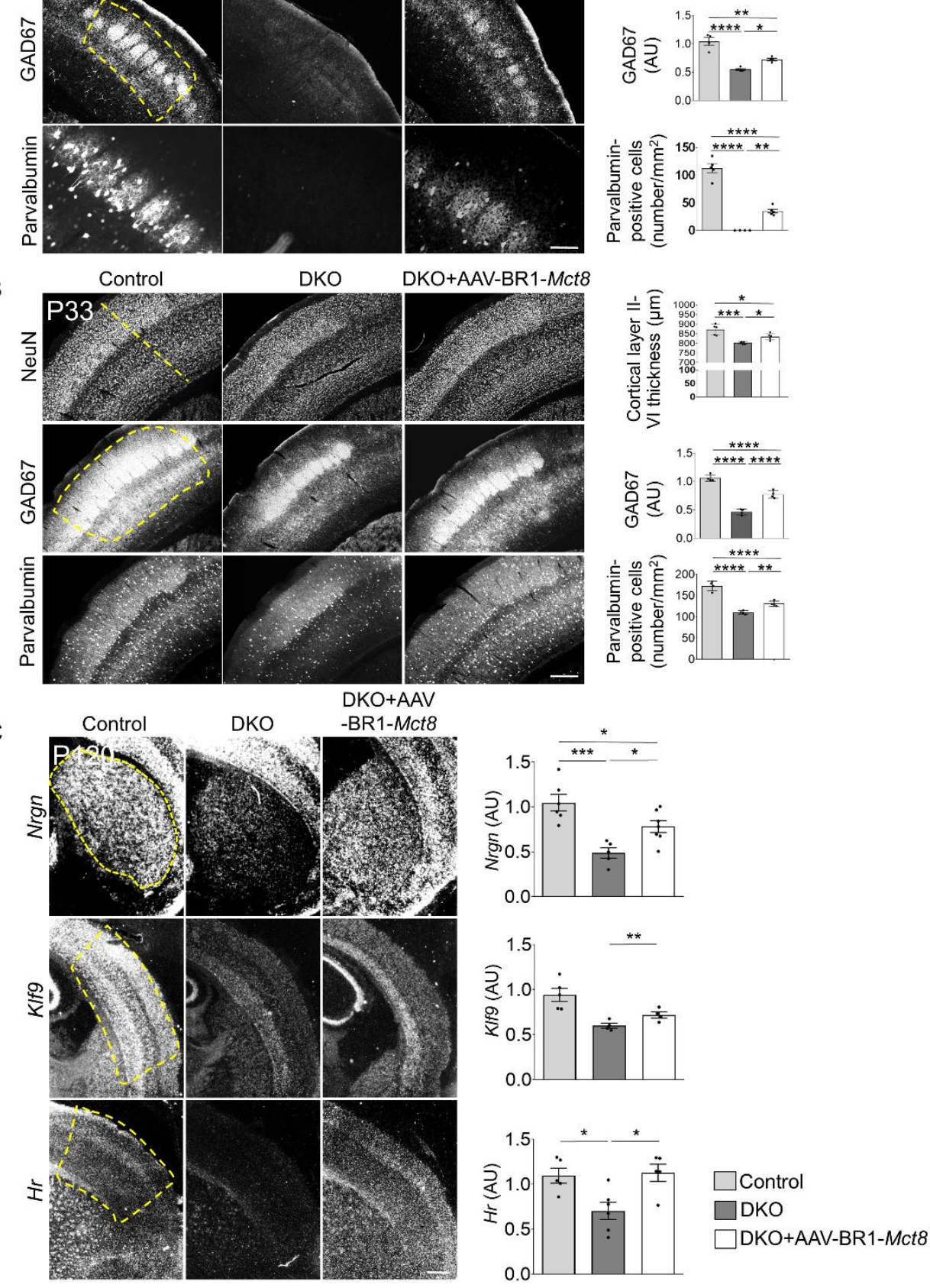

Figure 2. AAV-BR1-Mct8 treatment improves neuronal morphology and gene expression.

(A) Administration of AAV-BR1-Mct8 at P0 to DKO mice increased thickness of the molecular layer in the cerebellar vermis as well as the relative fluorescence intensity of GAD67- and parvalbuminpositive interneurons of the sensorimotor cortex at P12. One-way ANOVA for molecular layer, $\mathrm{F}(2 / 15)=40.0, P<0.0001$. One-way ANOVA for GAD67, $F(2 / 9)=32.36, P<0.0001$. One-way ANOVA for parvalbumin-positive neurons, $F(2 / 11)=108.9, P<0.0001$. Scale bar, $50 \mu \mathrm{m}$ (upper panel) Scale bar, $200 \mu \mathrm{m}$ (middle and lower panel) (B) Administration of AAV-BR1-Mct8 at P0 improved the thickness of the somatosensory cortex layers II-VI and the relative fluorescence signal intensity of GAD67- and 
bioRxiv preprint doi: https://doi.org/10.1101/2021.12.05.471343; this version posted December 9, 2021. The copyright holder for this preprint (which was not certified by peer review) is the author/funder, who has granted bioRxiv a license to display the preprint in perpetuity. It is made available under aCC-BY 4.0 International license.

parvalbumin-positive interneurons in the cortex at P33. One-way ANOVA: cortical thickness, $F(2 / 12)=16.4, P=0.0004$; GAD67, $F(2 / 9)=102.0, P<0.0001$; parvalbumin, $F(2 / 9)=63.01, P<0.0001$. (C) AAV-BR1-Mct8 injected at P0 increased the expression of Nrgn in the striatum and $\mathrm{Klf} 9$ and $\mathrm{Hr}$ in the cortex at P120. Gene expression was investigated by in situ hybridization. Scale bar, $100 \mu \mathrm{m}$. Oneway ANOVA: Nrgn, $\mathrm{F}(2 / 15)=12.8, P=0.0006 ; \mathrm{Klf} 9, \mathrm{~F}(2 / 10)=10.5, P=0.0035 ; H r, F(2 / 13)=6.857$, $P=0.0093$. Each dot represents one animal. Means \pm SEM are shown. ${ }^{*}, P<0.05 ;{ }^{* *}, P<0.01 ; * * *$, $P<0.001 ; * * * *, P<0.0001$ (Holm-Sidak's posthoc test). 
bioRxiv preprint doi: https://doi.org/10.1101/2021.12.05.471343. this version posted December 9, 2021. The copyright holder for this preprint (which was not certified by peer review) is the author/funder, who has granted bioRxiv a license to display the preprint in perpetuity. It is made available under aCC-BY 4.0 International license.

Figure 3
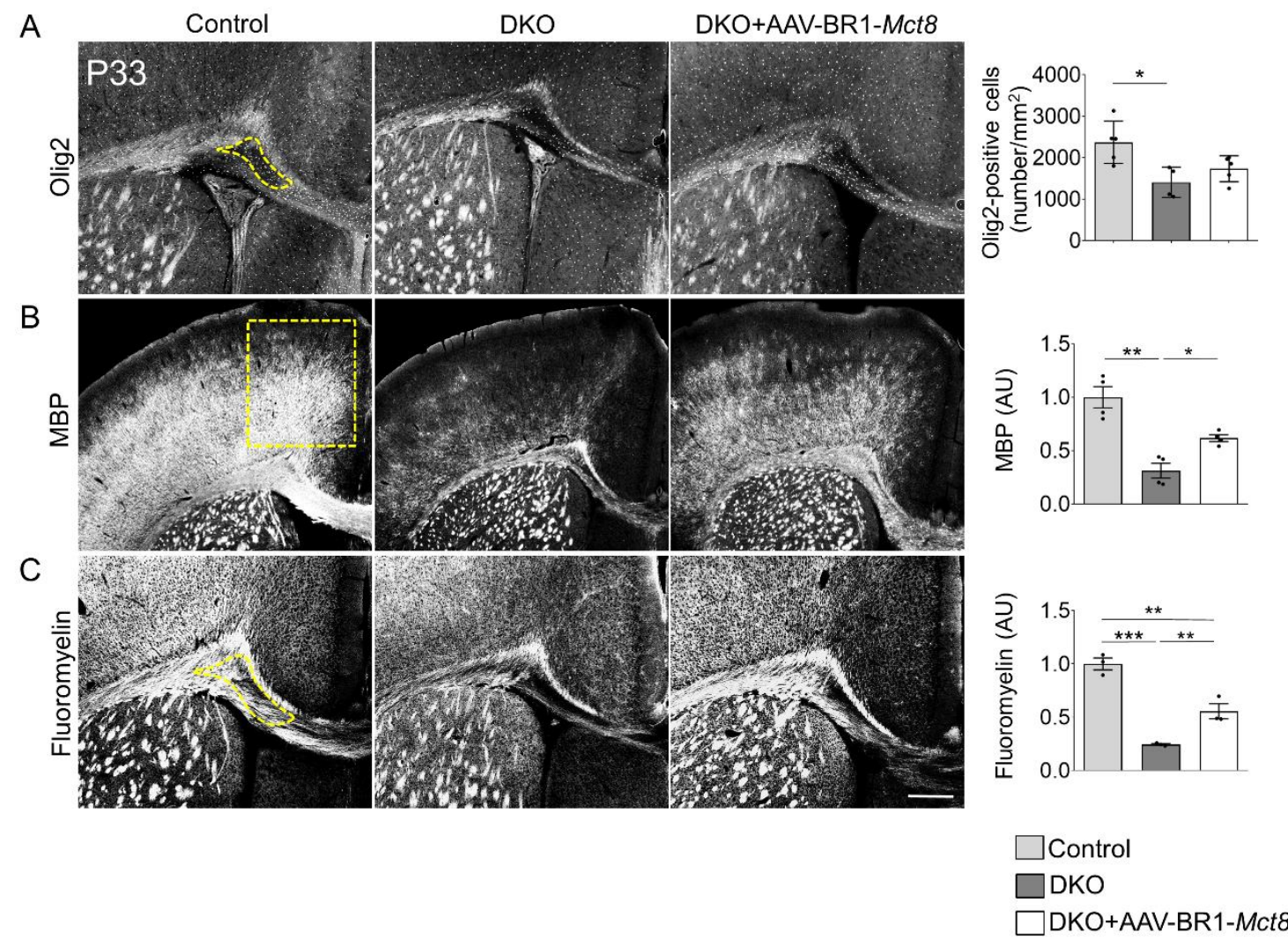

Figure 3. AAV-BR1-Mct8 treatment increases oligodendrocyte numbers and myelination.

Treatment of DKO mice at PO improved several parameters of myelination at P33. (A) The reduced number of Olig2-immunopositive oligodendrocytes in the corpus callosum was slightly but nonsignificantly increased in DKO treated with AAV-BR1-Mct8. Scale bar, $100 \mu \mathrm{m}$ One-way ANOVA, $F(2 / 11)=6.595, P=0.0131 .^{*}, P<0.05$ (Holm-Sidak's posthoc test). (B) AAV-BR1-Mct8 improved myelin basic protein (MBP) levels in the cortex of DKO mice. MBP was detected by immunostaining. Scale bar, $100 \mu \mathrm{m}$. Welch's ANOVA test, $\mathrm{W}(2 / 4.96)=14.8, P=0.0081$. $^{*}, P<0.05 ;{ }^{* *}, P<0.001$ (Tamhane's T2 posthoc test). (C) Compact myelin stained by Fluoromyelin was diminished in the cortex of untreated DKO but improved by treatment with AAV-BR1-Mct8. One-way ANOVA, $F(2 / 6)=53.15, P=0.0002 . * *$, $P<0.01 ;{ }^{* * *}, P<0.001$ (Holm-Sidak's posthoc test). Each dot represents one animal. Means $\pm \mathrm{SEM}$ are shown. 
Figure 4

A Rotarod

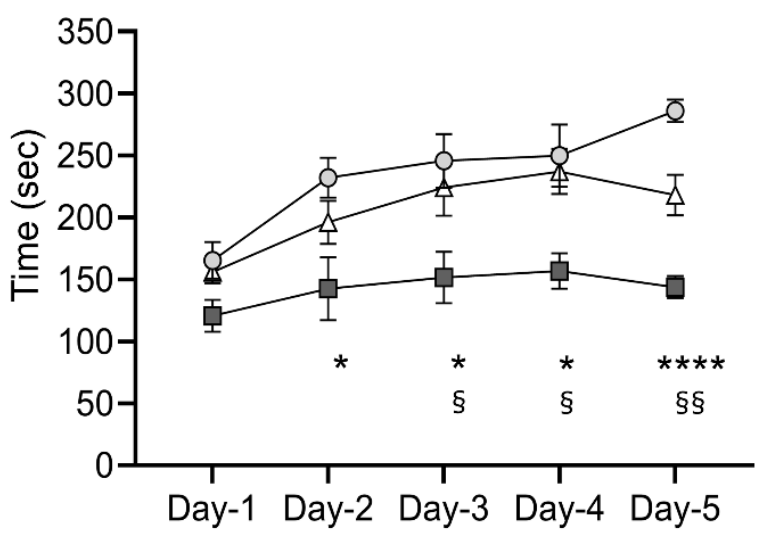

-o- Contro

$\rightarrow-$ DKO

$\triangle \quad$ DKO+AAV-BR1-Mct8

* Control vs DKO

$\S \quad$ DKO vs DKO+AAVBR1-Mct8

B

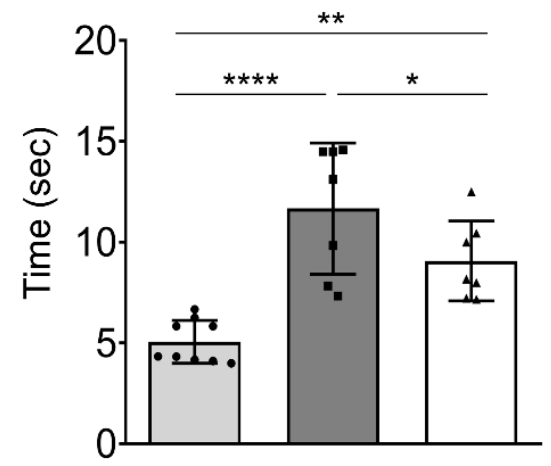

D

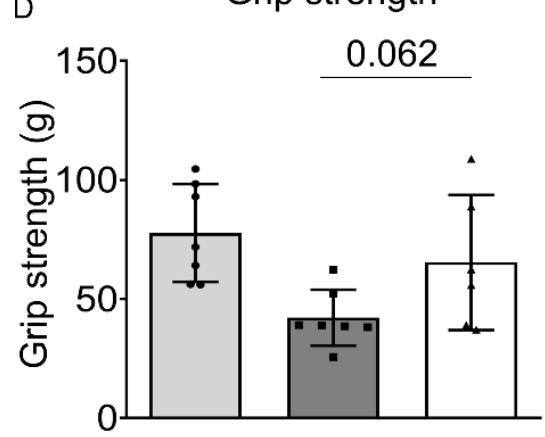

C

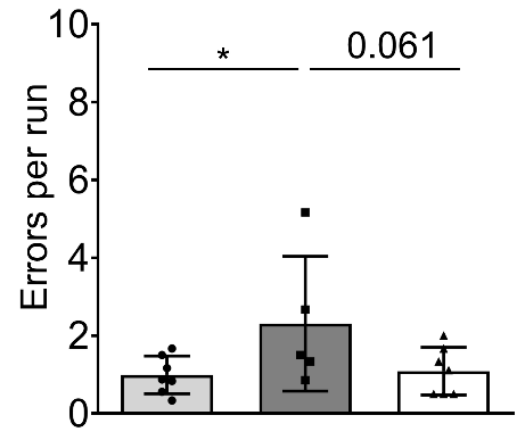

Figure 4. AAV-BR1-Mct8 treatment improves motor function in DKO mice.

(A) AAV-BR1-Mct8 treatment at P0 prolonged the time DKO mice were able to balance on the rotarod as a sign of improved coordination and motor learning. Mice were assessed on 5 consecutive days starting at P120. Repeated-measures ANOVA, $F(2 / 14)=11.85, P=0.001$. (B, C) AAV-BR1-Mct8 treatment reduced the time DKO mice needed to cross the beam and led to a trend towards fewer errors, indicating better motor coordination. One-way ANOVA for time, $F(2 / 20)=18.56, P<0.0001$. Kruskal-Wallis test for errors, $P=0.215$. (D) AAV-BR1-Mct8 treatment increased the grip strength of DKO mice in comparison to control animals. One-way ANOVA, $F(2 / 17)=5.25, P=0.017$. *, $\S P<0.05$, $* *, \S P<0.01, * * * * P<0.0001$ (Holm-Sidak's posthoc test). ns, nonsignificant. Each dot represents one animal. Means \pm SEM are shown. 